\title{
Small-scale geologic evidence for Vistulian decline cooling periods: case studies from the Łódź Region (Central Poland)
}

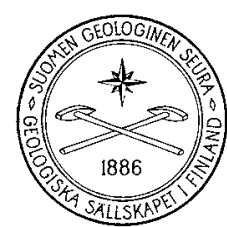

VERTAISARVIOITU KOLLEGIALT GRANSKAD PEER-REVIEWED

\author{
Danuta A. Dzieduszyńska*and Joanna Petera-Zganiacz \\ Department of Geomorphology and Palaeogeography, Faculty of Geographical Sciences, \\ University of Łódź, Narutowicza str. 88, 90-139 Łódź, Poland
}

\begin{abstract}
This study concerns small-scale features in the form of denivation structures, periglacial involutions, sharp-edged blocks, fragipan layers and frost fissures observed in various depositional environments of Central Poland. These are terrestrial evidence for the Vistulian (Weichselian) decline cool-climate intervals (Older Dryas and Younger Dryas). The structures developed in the presence of either permafrost or deep seasonal frost. In this study, the authors analyse their distinctive properties and origins, and their relations to the sedimentary successions and morphogenetic processes. The study demonstrates that the discussed features can be useful supplementary diagnostic markers for the comprehensive reconstruction of cold environmental conditions.
\end{abstract}

Keywords: oversnow deposits, involutions, frozen blocks, Older Dryas, Younger Dryas, cold-climate morphogenetic processes

*Corresponding author (e-mail: danuta.dzieduszynska@geo.uni.lodz.pl)

Editorial handling: Pertti Sarala (pertti.sarala@gtk.fi)

\section{Introduction}

Despite their relatively short durations, the Vistulian (Weichselian) decline cooling periods during the Older and Younger Dryas promoted significant changes in sedimentary environments. These changes were recorded in river patterns, the intensification of slope processes and the formation of cold-climate aeolian sequences in dunes and coversands (e.g. Koster, 1995; Antoine et al., 2003; Starkel et al., 2015). Major geomorphological responses to the climatic shifts were accompanied by small-scale processes, which complete the picture of environmental changes. The small-scale evidence for cool climate is sometimes assumed to be limited to strictly local phenomena and is neglected in comprehensive palaeogeographical interpretation. The identification of such evidence is not always 


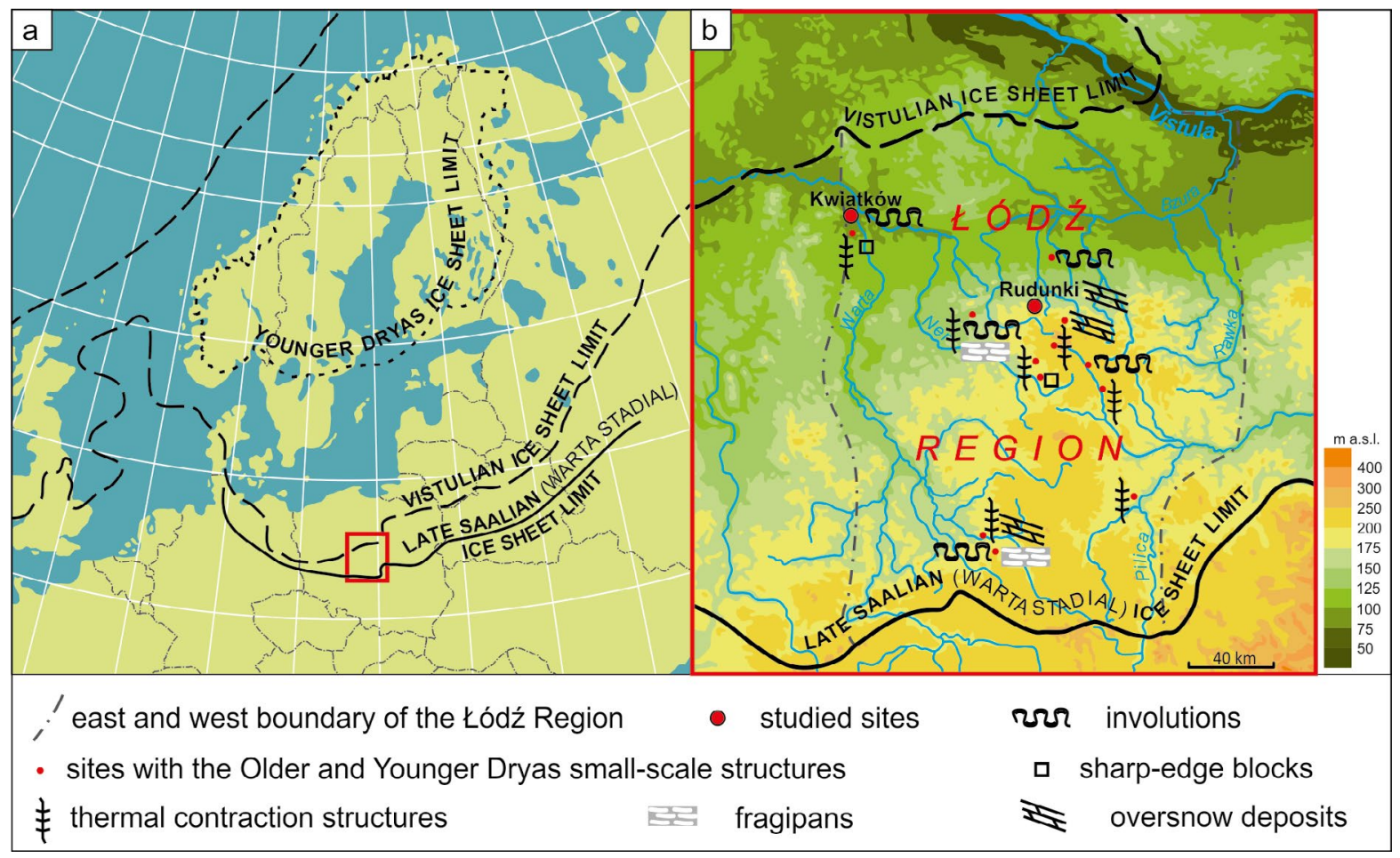

Figure 1. Łódź Region in relation to selected glacial limits (a) and hypsometry of the Łódź Region with distribution of the presented small-scale features (b) (references in the text).

obvious, because the near-surface position and soil-weathering processes could seriously blur the diagnostic features. On the other hand, the smallscale evidence from different sedimentary archives can be compiled to become valuable markers of conditions which affected the development of Older and Younger Dryas cold-climate successions.

Small-scale cold evidence is understood as phenomena, which generally only slightly influence the geological or geomorphological pattern, but, in the authors' opinion, it is outstanding in reconstructing the instability of the environment in the Vistulian decline. The mechanisms responsible for their formation are connected with cold domains of either permafrost or rigorous seasonal frost conditions. Cold-related processes reworked river bottoms locally, while thawing facilitated sediment movement, and wind action contributed on a large scale.

Based on case studies from some localities in the Łódź Region (Fig. 1), this study discusses the properties of denivation structures fashioned as oversnow deposits, and the details of a newly recognized site with periglacially involuted sediments and sand blocks preserved in alluvia. The authors aim to highlight their potential as supplementary diagnostic markers to understand cold environments. The present study is focused on the analysis of relict small-scale features reported from the Older and Younger Dryas sediments with defined stratigraphical positions and indicating differences in the inventory of structures from these periods in relation to the specifics and evolution stages of sedimentary environments.

The choice of the Łódź Region as a type locality for discussing the presented issue is supported by the very good recognition of its palaeogeographical development in the Pleistocene, especially in the Vistulian. In the studies carried out in the area, novel concepts of environmental evolution under periglacial conditions have been formulated and developed (Dylik, 1953, 1967; Dylikowa, 1967; 


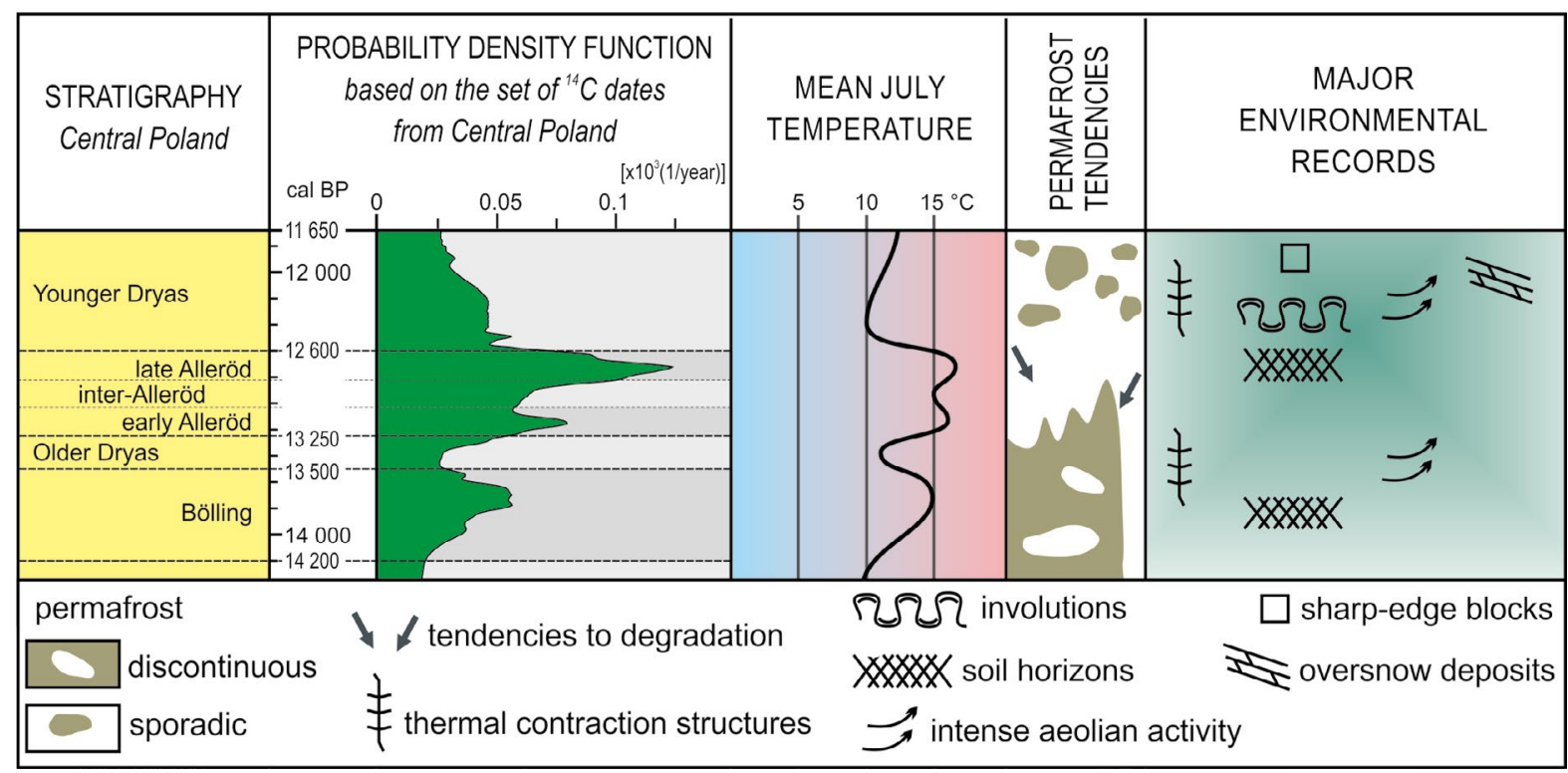

Figure 2. Features of natural environment in the Łódź Region during the Vistulian decline (after Dylikowa, 1967; Klatkowa, 1996; Manikowska, 1995; Petera, 2002; Dzieduszyńska, 2011, in press; Roman et al., 2014).

Turkowska, 1988; Manikowska, 1995), which has created a very good basis for understanding the palaeogeographical context of small-scale structures in narrow time spans in the analysed cold time spans.

\section{Climatostratigraphy}

The conditions of the Vistulian decline in the Łódź Region reflect rapid changes between warmer and cooler phases, superimposed on the general warming trend observed on a global scale (Lowe et al., 1994; Brauer et al., 2000; Rasmussen et al., 2014). The timescale covers the period between $14.2 \mathrm{ka} \mathrm{cal} \mathrm{BP}$ and $11.65 \mathrm{ka} \mathrm{cal} \mathrm{BP}$ and includes the Bölling, Older Dryas, Alleröd, and Younger Dryas oscillations (Fig. 2).

Reconstruction of the palaeoenvironmental changes in the Łódź Region is based on proxy records from organic successions of peatbogs (Dzieduszyńska \& Forysiak, 2015) and on geological and geomorphological evidence (Manikowska, 1985, 1996; Turkowska, 1988, 2006; Dzieduszyńska, 2011; Dzieduszyńska et al., 2014;
Roman et al., 2014; Petera-Zganiacz et al., 2015). Estimation of the regional duration of particular periods is based on a set of 175 radiocarbon dates (Dzieduszyńska, in press). The Bölling, of a duration of ca. 700 calendar years (14.2-13.5 ka cal BP), was a warm phase with a mean July temperature of about $15^{\circ} \mathrm{C}$. An initial soil developed under vegetation cover consisting of loose willow-birch forest. Drier and colder climatic conditions, with summer temperatures between $10.0^{\circ} \mathrm{C}$ and $13.0^{\circ} \mathrm{C}$ and the disappearance of forest communities, prevailed in the following cooling phase, the Older Dryas, which lasted ca. 250 calendar years (13.5-13.25 ka cal BP). The Alleröd, with the temperature raising up to $17^{\circ} \mathrm{C}$, lasted ca. 650 calendar years $(13.25-$ $12.6 \mathrm{ka} \mathrm{cal} \mathrm{BP)}$ and was a time of pedogenesis. It was a tripartite period of warming subdivided by the ca. 200-calendar-year-long inter-Alleröd cold oscillation with a temperature drop of about $2{ }^{\circ} \mathrm{C}$. Botanically the Alleröd consisted of a birch phase followed by a phase dominated by pine communities. A much colder climate is identified in the Younger Dryas. Its first part was the coldest and driest, with summer temperatures dropping to 
$10.0^{\circ} \mathrm{C}$ and coldest months from -25 to $-15^{\circ} \mathrm{C}$, and vegetation dominated by heliophytes. In the second part, mean July temperatures of $12-13{ }^{\circ} \mathrm{C}$ and increasing humidity were inferred from a recorded reduction in dry habitat plants. The Younger Dryas lasted ca. 950 calendar years (12.6-11.65 ka cal BP).

Vistulian decline cold-climate conditions are usually discussed in the context of a presence of permafrost. According to the most common opinion, in the northwestern continental and central European territory, the ultimate permafrost disappearance took place during the Alleröd (Böse, 1995; Kozarski, 1996; Goździk, 1996; Klatkowa, 1996; Marks, 1996). Recently, based on studies in peatbogs of the Łódź Region, Petera-Zganiacz \& Dzieduszyńska (2017) have proven that the permafrost re-aggraded locally in the Younger Dryas.

\section{Regional setting}

The area of investigations is located in the Polish part of the northern central European Lowland, in the range regionally named the Łódź Region (Turkowska, 2006). It is an old morainic area, limited from the south by the maximum extent of the late Saalian ice sheet (Warta Stadial of the Odranian Glaciation in Polish stratigraphy) whereas in the north it reaches the marginal zone of the Vistulian ice sheet. The longitudinal boundaries of the Łódź Region are delimited by morphological criteria - in the west, the area is bounded by the Warta River valley and in the east by the Pilica and Bzura River valleys (Fig. 1b).

In the middle part of the region there is meridional elevation, with heights up to $250 \mathrm{~m}$ a.s.l. Most of that area has a typical flat or slightly undulating lowland landscape. The relief is more diversified on the outskirts, especially in the northern part where the terrain descends through a series of broad flat levels separated by zones of steeper slopes (Fig. 1b). The study area remained under periglacial conditions during the Vistulian cold period, which largely reworked the glacial relief (Turkowska, 2006). Following the last ice sheet retreat (dated OSL at ca. $18.7 \mathrm{ka}$, after Roman et al. (2014)) the area experienced a rapid transition from the cold domain to the present interglacial conditions, which had a strong impact on the environment.

The sites with small-scale features have been reported from the geomorphologically diverse zones of the Łódź Region: slopes of dry periglacial valleys, river valleys, terraces, fossil slopes of dunes, and coversands. Detailed studies were conducted in the dry periglacial valley in the northern part of the region (Rudunki site) and in the Warta River valley in the north-west (Kwiatków DJ site and Kwiatków JJ site) (Fig. 1b). The Rudunki site (N 51 ${ }^{\circ} 52^{\prime} 50^{\prime \prime}$, $\mathrm{E} 19^{\circ} 25^{\prime} 50^{\prime \prime}, 195 \mathrm{~m}$ a.s.l.) is located on the slope of the upper section of the N-S-oriented dry valley, within a gravel pit. The Kwiatków DJ site (N 52 5'58”, E 18 40'38”, $96.3 \mathrm{~m}$ a.s.l.) and Kwiatków JJ site (N 525'30”, E 1840’38”, 97.5 m a.s.l.) were documented within the Adamów Brown Coal open pit, in the sediments of the lower terrace on the left side of the Warta valley.

\section{Methods}

During the field studies, a range of geological methods was used. The properties of sediments were inferred from analysis of textural and structural features. Grain-size analysis was carried out for the Rudunki profile. Its results were used to calculate Folk \& Ward (1957) coefficients: mean grain size, standard deviation and skewness. Analysis of sedimentary structures was carried out at the Kwiatów DJ and Rudunki sites according to the Miall (1978) code modified by Zieliński (2015). Based on the recognised lithofacies, sedimentary environments have been interpreted. Directional measurements (strikes and dips) were applied to study discontinuous deformation structures at the Rudunki site. Two samples of organic material from the Kwiatków DJ profile were radiocarbon dated and calibrated using the IntCal13 calibration data set (Reimer et al., 2013) and the OxCal calibration programme ver. 4.2.3. (Bronk Ramsey, 2009). 


\section{Results and interpretation}

\subsection{Oversnow deposits}

Sedimentary series of the oversnow deposit at the Rudunki site mantles the slopes of two dry periglacial valleys (Fig. 3a). Series thickness varies between $0.3 \mathrm{~m}$ in the uppermost slope section and $0.8 \mathrm{~m}$ downslope. It rests on the Vistulian infilling of dry valleys, which is common in the Łódź Region: this infilling of sandy-silty series deposited under permafrost conditions by slopewash in the Plenivistulian covered by an allochtonic gravel pavement, which is a key Upper Plenivistulian horizon (a synthesis of that issue is provided by Turkowska, 2006). From the top, structureless sand cover (Fig. 3c) overlies it. The series is built mostly of medium and fine sand, and also thicker sand and gravel fraction and even coarse pebbles of over $10 \mathrm{~cm}$ in diameter are present. Grain-size composition (Folk \& Ward, 1957) points to a mean grain size of about 2 phi, poor sorting and slight enrichment in the coarser fraction. Horizontal lamination of the material prevails, and locally the layers are deflected or ripples appear (Fig. 4). Gravel material accentuates lamination, while pebbles are chaotically distributed. The distinguishing feature of the series is its discontinuous deformations in the form of distinct small faults and fissures (Fig. 3c, d). These are reversed and normal faults with a throw of a few centimetres. The disturbances create a network of cracks, which limit packages of rotated (but undeformed) material, usually highlighted with hard limonitic streaks. Within the blocks, strikes and dips are variable, even in units directly adjacent to each other (Fig. 3b).

The origin of the series is connected with denivation phenomena. The leading process was most probably slopewash over frozen snow patches, which had been preserved for longer than one season. Directional parameters set separately for individual walls of the pit indicate that the strike of the layers and the faults are approximately parallel to the valley axes (Fig. 3b). We assume that the slope surface was uneven and that the depositional process in places where some obstacles occurred (e.g. frozen snowdrifts) caused disturbances to the lamination. In addition, the admixture of coarser material may have resulted from unevenness of the surface, which, together with transport in a shallow water environment, facilitated transition to turbulent flow (Gradziński et al., 1986). Larger pebbles might have been transported by mudflow. Discontinuous deformations were formed by material collapse due to denivation. The wellordered strike directions of faults and fissures result from settling on a sloping surface, whereas the disordered pattern of the dip values indicates the multi-directional course of the deformation process (Fig. 3b). The origin of the oversnow deposit is approximately dated at the Younger Dryas. Environmental arguments for activation of efficient slope processes at that time, especially in parts of the study area with steeper slopes were provided by Dzieduszyńska (2011). The age $12.8 \pm 1.9$ ka has been also recognized by TL dating in the 1980 s (Klatkowa, 1989); dating has not been repeated.

\subsection{Involutions}

Small-scale structures were documented at the Kwiatków DJ site, which is located in the east wall of the Koźmin North (Kwiatków) open pit of the Adamów Lignite Mine (Fig. 5a), within a profile of fluvial sediments. The profile of alluvium includes $3.4 \mathrm{~m}$ of mostly sandy deposits with two horizons of organic series involved in the deformation. In the lower part of the profile, sand and sandy silt occur. Horizontal and ripple lamination prevails, but in medium-grained sand, trough cross stratification appears (Fig. 5b). The deposition took place in the not-very-dynamic sedimentary environment of the overbank facies of the braided river (Zieliński, 2015). Such fluvial deposits are typical in the studied Warta River valley section, and are dated at the end of the Upper Plenivistulian (Petera, 2002). Above lays organic silt of about $20 \mathrm{~cm}$ thick, containing remains of wood. The layer developed 


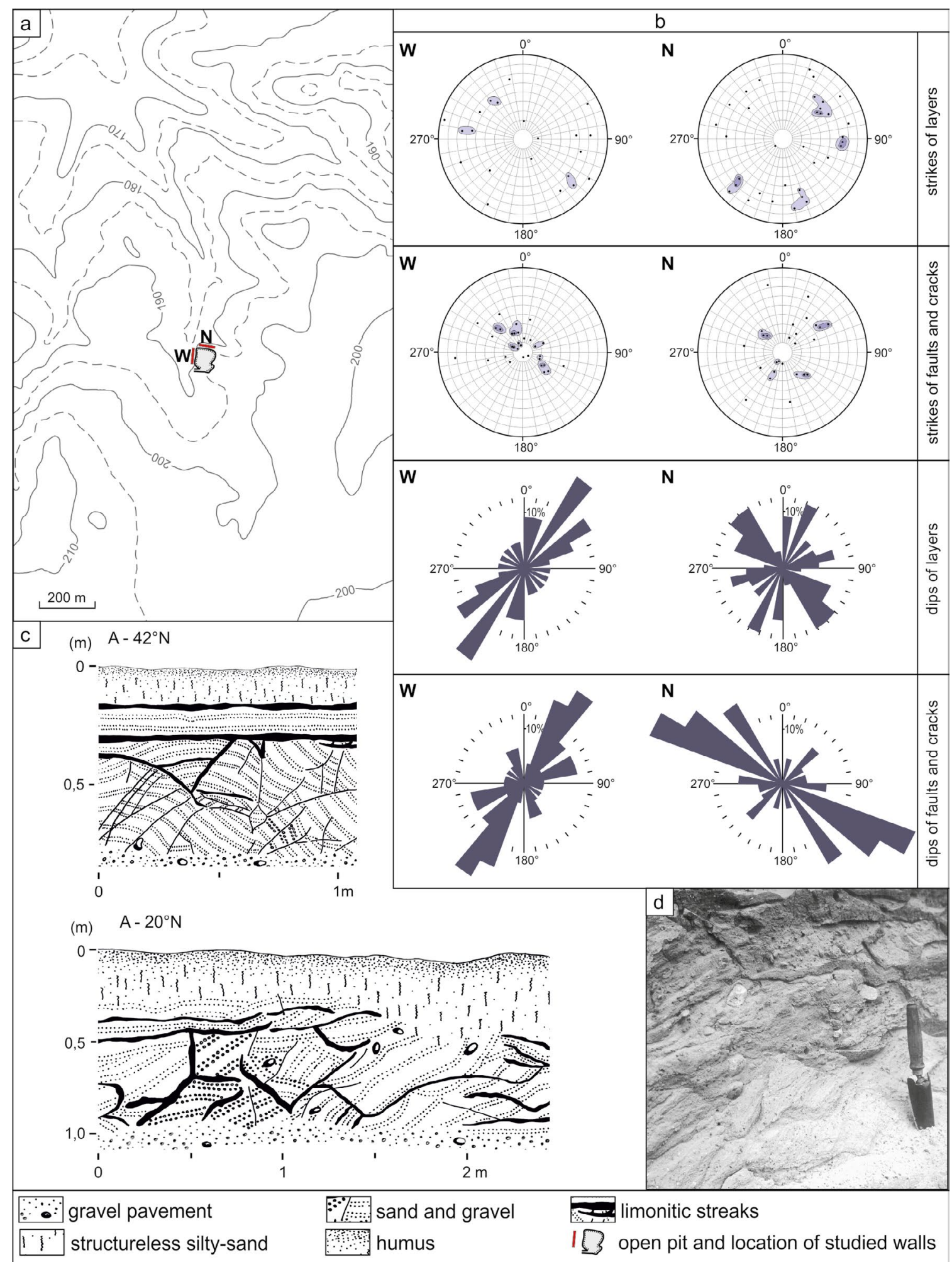

Figure 3. Rudunki site: a) morphological situation of the site, b) directional elements of layers and discontinuous deformations, $c$ ) schemes of excavation walls and d) oversnow deposits. 


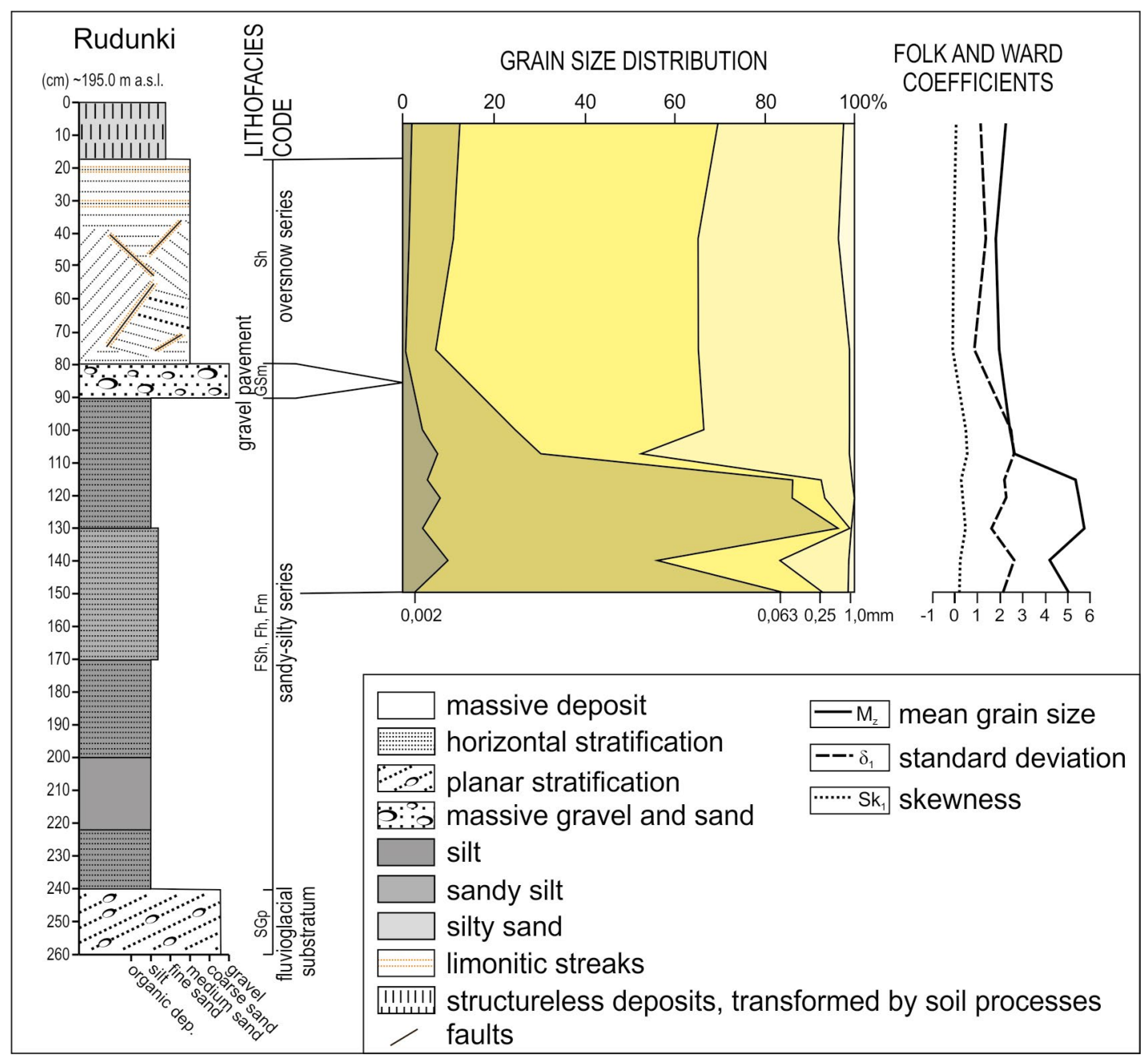

Figure 4. Sedimentary profile and granulometric characteristics of deposits at the Rudunki site.

on the distal part of the floodplain, where the slow accumulation was not interrupted by fluvial processes. Radiocarbon dating of organic silt gave a result of $10.72 \pm 1.0 \mathrm{ka}{ }^{14} \mathrm{C}$ BP $(12.79-12.43 \mathrm{ka}$ cal BP; prob. 95.4\%; MKL-3335), indicating its Younger Dryas age (Fig. 5c). At the boundary between the organic layer and the underlying sandy series, small involutions of about $10 \mathrm{~cm}$ high developed as quite regular structures (Fig. 5c).

The organic layer is covered by $60-\mathrm{cm}$-thick mineral deposits, which began to accumulate with massive silt and ripple-laminated sandy silt, followed by trough cross-stratified medium sand. This sedimentary succession reflects the increasing dynamics of fluvial processes with a tendency to aggradation (Zieliński, 2015). The accumulation of the second organic-silt layer indicates a sedimentary environment returning to extremely low dynamics (Fig. 5b). The layer thickness reaches several centimetres and, as does the lower one, contains wood. The tree remains were radiocarbon-dated at $11.36 \pm 0.7 \mathrm{ka}{ }^{14} \mathrm{C}$ BP $(13.34-13.07 \mathrm{ka}$ cal BP; prob. $95.4 \%$; MKL-3334) (Fig. 5c). The dating result gave an older value than for the lower organic layer, so we conclude that the wood must have been redeposited. The layer is undeformed in places, and in places involutions developed, involving the underlying mineral layer. The vertical dimensions 


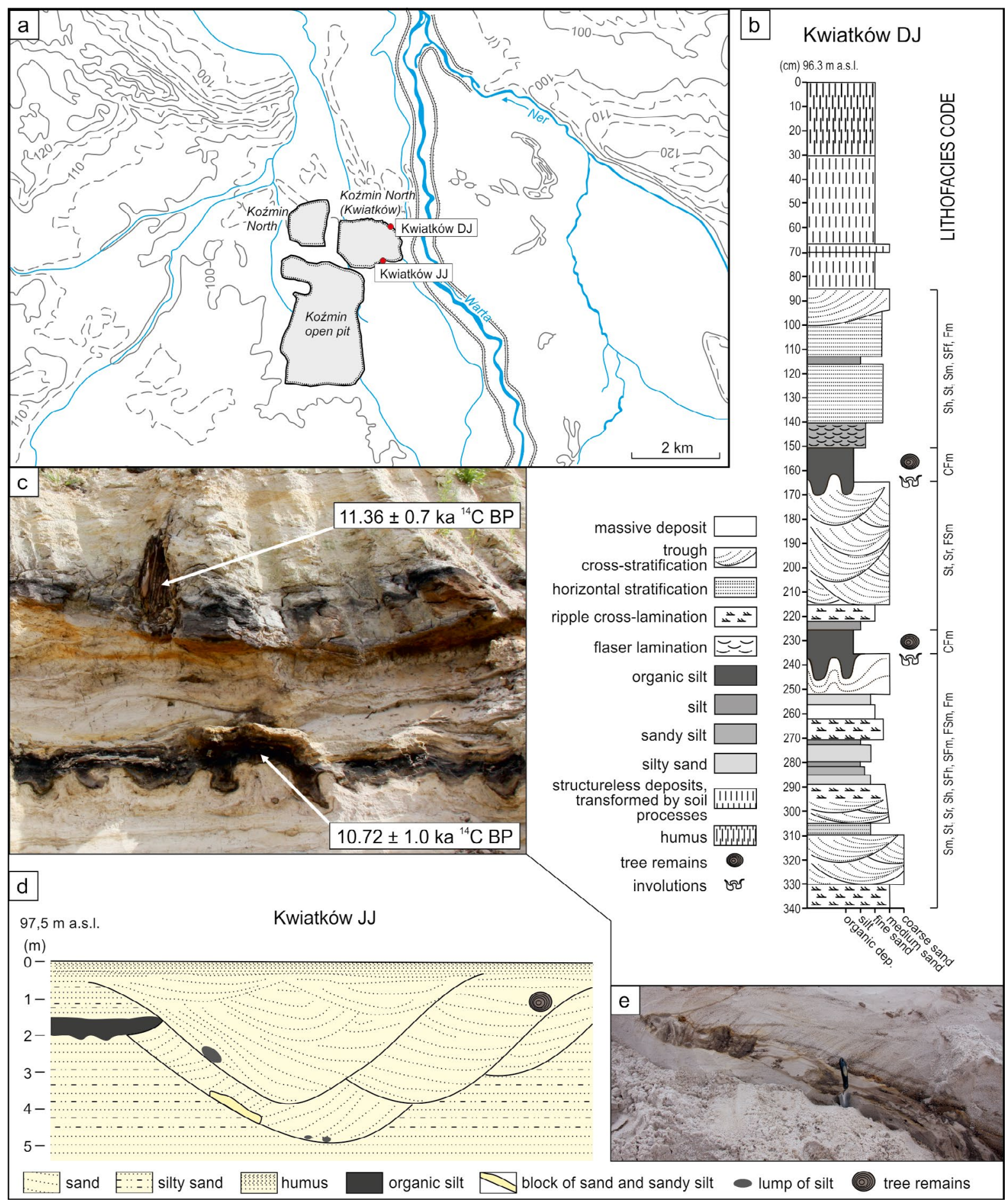

Figure 5. Kwiatków sites: a) morphological situation of the sites, b) sedimentary profile, c) involution at the base of the organic horizon and ${ }^{14} \mathrm{C}$ datings, d) situation of frozen blocks in the channel and e) frozen block buried in Warta River alluvium. 
of the structures reach 10 to $20 \mathrm{~cm}$, whereas the horizontal dimensions vary from less than 10 to more than $50 \mathrm{~cm}$.

The top part of the profile $(0.15 \mathrm{~m})$ is dominated by fine grained sands and sand with silt. It starts with flaser lamination in fine deposits and is followed dominantly by horizontally laminated sand. The sequence of the sedimentary structures reflects increasing dynamics of fluvial processes (Zieliński, 2015). Near the topographic surface soil processes (Fig. 5b) have disturbed the structure of deposits.

In a similar geologic setting, small involutions were documented in the south part of the studied Warta valley section. During previous studies, six types of involutions had been distinguished (Petera-Zganiacz \& Dzieduszyńska, 2017), and, in terms of their features, deformations described at the Kwiatków DJ site allow them to be classified as the diapiric type in the lower organic layer and the diapiric and flame-like involution type in the upper horizons. As with the other nearby sites, the age of the disturbed sediment and the comparable palaeogeographic conditions in which the involutions developed both indicate that they were formed in the periglacial environment of the Younger Dryas, which provides evidence of cold climate influencing sediment transformation during the Vistulian decline.

\subsection{Frozen blocks}

During the studies carried out in the Koźmin North (Kwiatków), another type of small-scale structures was recognized to complete the picture of past conditions; namely, a block of sand and sandy silt deposited within the river channel (Kwiatków JJ site). The block rests in the bottom of the channel about $4 \mathrm{~m}$ below the present surface and $2 \mathrm{~m}$ below the surface active during the channel development (Fig. 5d, e). The results of the previous studies show that a system of channels which formed in the Warta River valley in the younger part of the Younger Dryas eroded the frozen surface 2-3 m down (Turkowska et al., 2004; Forysiak, 2005;
Petera-Zganiacz et al., 2015). The significant dynamics of the fluvial environment resulted in fast accumulation of channel fills, which favoured the burial of eroded blocks, but preservation of sandy and sandy silty material was possible thanks to its frozen state (Dylik, 1969; Turkowska, 1988; Mycielska-Dowgiałło, 1998).

\section{Discussion}

Unlike in northwestern continental Europe, the climatic conditions in central Poland during the cold periods of the Vistulian decline (Isarin et al., 1998; Isarin \& Renssen, 1999; Renssen et al., 2000; Brauer et al., 2008) were not fully suitable for the formation of mature periglacial features. In central Europe, there is still very scant evidence of past permafrost to directly prove a cold climate. This could be due to the atmospheric circulation pattern, which at that time generated an increasing amount of snowfalls eastwards, which protected the ground from frost penetration (Kozarski, 1993; Isarin et al., 1998). Permafrost tended to degrade because of the general warming and relatively short intervals of cooling periods (Fig. 2). The disappearance of frost in the ground varied in space and time, so that locally, under favourable site conditions, it persisted longer and re-aggraded more easily in response to the returning cold. As follows from the study by Dzieduszyńska \& Petera-Zganiacz (2016), permafrost-related structures developed in the sites favourable to frozen ground re-aggradation, such as beneath peatbogs within river valleys.

The occurrence of discontinuous permafrost patterns should oblige researchers undertaking a comprehensive palaeoenvironmental synthesis of the Vistulian decline to take into account a larger inventory of features than only strictly permafrostrelated ones. Although the features presented in this contribution are climate-induced phenomena, their formation also depends on local morphological and lithological factors. The largest number of small-scale features of short cooling periods in the Łódź Region has been reported from the 
geomorphologically diverse zones of the study area: slopes of dry periglacial valleys, river valleys, terraces, fossil slopes of dunes, and coversands.

Cold-climate morphological phenomena are clearly expressed in the slope environment in the study area and was best recognized at the Rudunki site (Figs. 1b, 3, 4). The origin of the series is attributed to the deposition by wash, mudflow and wind on frozen snow cover, while the development of collapse structures resulted from denivation processes, probably without permafrost involved. Since geochronological control of these features is approximate, it follows from the climatic characteristics that the Younger Dryas deep cooling was most favourable for the formation of oversnow series (Dzieduszyńska, 2011). A similar mechanism was recognized for the process by which the niveoaeolian, niveofluvial and niveo-fluviatile deposits developed in the Netherlands (van der Hammen \& Maarleveld, 1952). Familiar features related to the niveo-aeolian sedimentation have been reported from the present cold zone (Koster \& Dijkmans, 1988).

Small slides and flowage structures recorded on the steep fossil slopes of late-glacial dunes below the Alleröd soil (Manikowska, 1985, 1995) are also connected by denivation processes (Fig. 1b). Their origin is attributed to the mass-wasting of soil and sand cemented with plant roots or with fragipan, which provided a solid surface of movement during melting of snow layers in the niveo-aeolian environment (Koster \& Dijkmans, 1988).

Another phenomenon indicative of Vistulian decline cold-climate periods is the presence, in aeolian covers and dunes, of densified layers slightly enriched in $\mathrm{Fe}, \mathrm{Al}$ and $\mathrm{Si}$, which were most commonly registered within the Older Dryas series below the Alleröd soil (Manikowska, 1985, 1995; Twardy, 2008) (Fig. 1b). These layers - described as "fragipan" - could have resulted from the consolidation of ice lenses and the formation of increased density zones after melting interacted with soil liquefaction (van Vliet-Lanoë \& Langhor, 1981; Scalenghe et al., 2004). Water thermomigration and precipitation of iron and clay on freezing probably also controlled the formation of the iron strips superimposed on the Alleröd soil.

The occurrence of small involutions is not conclusive evidence of a periglacial environment. Interpretation of their origin requires caution, and consideration of as many aspects of the local environment as possible (Anketell et al., 1970). In the Łódź Region, involutions connected with the Vistulian decline cold intervals were described from: soil horizons (Jurkiewiczowa, 1961); both dunes (Chmielewski, 1970; Twardy, 2008) and coversands (Goździk, 1973) for aeolian environments; and the boundary between sandy-silty series (deposit of mixed fluvio-aeolian-slope origin) and dune sands (Kasse et al., 1998). The best recognized involutions of the Younger Dryas age occur in the Warta River valley, where they were studied over a wide area of the brown-coal open pits and their development under frozen ground conditions has been proven (Petera, 2002; Petera-Zganiacz, 2016; PeteraZganiacz \& Dzieduszyńska, 2017). The present study completes the picture of the recognized inventory of such structures (Figs. 1b, 5b, c). Isarin (1997) has compiled the distribution of involutions of this age in Europe.

Diagnostic indicators for cold conditions survived buried in the alluvium of some rivers in the Łódź Region (Figs. 1b, 5d, e). The block of allochtonic material derived from frozen sediments presented in this study is one of a few examples recognized in the Łódź Region. Small sharp-edged lumps of medium-grained sand with preserved original laminated internal structure were found within channel deposits during previous studies of the Warta sediments (Petera, 2002; Turkowska et al., 2000, 2004; Petera-Zganiacz et al., 2015). Also in the Ner River valley, fossilized blocks of fluvially transported overbank deposits dated at the Younger Dryas with traces of postsedimentary deformations were recorded (Turkowska \& Dzieduszyńska, 2011). These features provide evidence of a floodplain freezing, as well as rapid accumulation under cold-climate conditions. Certainly, the erosion processes responsible for their formation must have been driven or significantly supported by thermal 
erosion (Dylik, 1969; Turkowska, 1988; MycielskaDowgiałło, 1998).

In deposits accumulated during the Vistulian decline, structures have been documented which developed due to thermal contraction (Figs. 1b, 2). The structures reported from the study area usually take the form of epigenetic frost fissures (Olchowik-Kolasińska, 1962; Goździk, 1973; Manikowska, 1996; Twardy, 2008), syngenetic frost fissures (Manikowska, 1995) or small sand wedges (Goździk, 1973; Manikowska, 1997), whereas well-developed ice-wedge pseudomorphs are scarce (Goździk, 1973; Kasse et al., 1998). Examples of thermal contraction structures provided from the regional literature do not indicate anything about their age, and the cited authors assign them to the Vistulian decline in general. Most of the dated thermal contraction features originated during the Older Dryas, when discontinuous permafrost aggraded in newly formed dunes and coversands (Goździk, 1996; Manikowska, 1995).

Interesting and significant features, which grew in the Younger Dryas cold interval, are icewedge casts, $-3 \mathrm{~m}$ deep and $-0.2 \mathrm{~m}$ wide and small narrow sand wedges described from the base of the aeolian dune sands in the Bełchatów brown-coal open pit (Kasse et al., 1998). In the Adamów brown-coal open pit, frost fissures were reported from fluvial sediments (Petera-Zganiacz \& Dzieduszyńska, 2017). The structures are $1.5 \mathrm{~m}$ long and only up to a few centimetres wide, and filled with sand in the bottom, host deposits in the middle, and overlying material in the top. The fissures developed because of repetitive cracking in broadly same position during at least a few winter seasons, which is proven by the occurrence of finger-like elementary veins in their lower parts. These frost fissures probably formed an initial polygonal system. During the Younger Dryas, the frost fissures could have developed on flat areas of river valleys (Petera-Zganiacz \& Dzieduszyńska, 2017), whereas Manikowska (1995) claims that the dune environment of that time did not provide suitable water conditions for ground ice formations. Also in northwest Europe, thermal contraction cracks of Younger Dryas age are scarce. They have been reported from the Mass River valley in the Netherlands by Bohncke et al. (1993) and in northeast Germany by Börner et al. (2011).

\section{Concluding remarks}

- Newly documented small-scale geologic evidence (oversnow deposits, small involutions, sandblocks in alluvium) were formed during the Younger Dryas period of the Vistulian decline.

- Based on the new findings and literature review, comparison between cold-climate evidence dated at the Older Dryas and that dated at the Younger Dryas points to a larger variety of smallscale structures having developed during the latter.

- The Older Dryas promoted the development of numerous frost fissures, mostly in aeolian environments, which is attributed to the Vistulian permafrost still having been present.

- For the Younger Dryas, frost fissures are less common; the shortage of these features can be explained by dry conditions and the absence of permafrost. In wetter localities (e.g. bottoms of river valleys or peatbogs) indirect proof related to frozen ground, such as sand-blocks in alluvium or small involutions, have been registered (in places where re-aggradation of permafrost was possible).

- Denivation structures prove that snow played a large role in the Younger Dryas environment; the thickness of snow cover increasing eastwards is in agreement with European palaeoclimatic simulations.

- The origin of the described structures was generally driven by climatic changes. Differences in the inventory of structures result from the delayed response of individual local sedimentary environments to the short events of the Vistulian decline. 
- The small-scale features are considered to have no quantitative climate-diagnostic value, but they can be successfully applied as supplementary markers of climate and environmental inferences, especially where they coincide.

\section{Acknowledgements}

We thank two anonymous reviewers for their valuable comments and suggestions which greatly improved the article. We are also grateful to the editor Pertti Sarala for his work on the manuscript.

Dylik, J., 1967. Solifluction, congelifluction and related slope processes. Geografiska Annaler 49, 167-177.

Dylik, J., 1969. Slope development affected by frost fissures and thermal erosion. In: Pewe, T.L. (ed.), The periglacial environment, past and present. McGill-Queen's University press, Montreal, pp. 365-386.

Dylikowa, A., 1967. Wydmy śródlądowe i ich znaczenie dla stratygrafii schyłkowego plejstocenu. In: Galon, R., Dylik, J. (eds), Czwartorzęd Polski. PWN, Warszawa, pp. 353371. (in Polish)

Dzieduszyńska, D., 2011. Ochłodzenie młodszego dryasu i jego efekty morfogenetyczne w regionie łódzkim. Acta Geographica Lodziensia 98, 104 p. (in Polish with English summary)

Dzieduszyńska, D.A., in press. Timing of environmental changes of the Weichselian decline (18.0-11.5 ka cal BP) using frequency distribution of ${ }^{14} \mathrm{C}$ dates for the Łódź region, Central Poland. Quaternary International. https://doi.org/10.1016/j.quaint.2017.08.012.

Dzieduszyńska, D. \& Forysiak, J., 2015. The Late Glacial organic sediments in palaeogeographical reconstructions (cases of the Łódź region). Bulletin of Geography, Physical Geography Series 8, 47-57.

https://doi.org/10.1515/bgeo-2015-0004

Dzieduszyńska, D. \& Petera-Zganiacz, J., 2016. Znaczenie torfowisk dla wnioskowania o reaktywacji zmarzliny $\mathrm{w}$ młodszym dryasie. Acta Geographica Lodziensia 105, 81-91. (in Polish with English summary)

Dzieduszyńska, D.A., Kittel, P., Petera-Zganiacz, J., Brooks, S.J., Korzeń, K., Krąpiec, M., Pawłowski, D., Płaza, D.K., Płóciennik, M., Stachowicz-Rybka, R. \& Twardy, J., 2014. Environmental influence on forest development and decline in the Warta River valley (Central Poland) during the Late Weichselian. Quaternary International 324, 99-114.

https://doi.org/10.1016/j.quaint.2013.07.017

Folk, R.L. \& Ward, W.C., 1957. Brazos River bar: a study in the significance of grain size parameters. Journal of Sedimentary Petrology 27, 3-26.

https://doi.org/10.1306/74d70646-2b21-11d7$8648000102 \mathrm{c} 1865 \mathrm{~d}$

Forysiak, J., 2005. Rozwój doliny Warty między Burzeninem a Dobrowem po zlodowaceniu warty. Acta Geographica Lodziensia 90, 116 p. (in Polish with English summary) 
Goździk, J., 1973. Geneza i pozycja stratygraficzna struktur peryglacjalnych w środkowej Polsce. Acta Geographica Lodziensia 31, 119 p. (in Polish with English summary)

Goździk, J., 1996. A permafrost evolution and its impact on some depositional conditions between 20 and $10 \mathrm{ka}$ in Poland. Biuletyn Peryglacjalny 34, 53-72.

Gradziński, R., Kostecka, A., Radomski, A. \& Unrug, R., 1986. Zarys sedymentologii. Wyd. Geologiczne, Warszawa, 628 p. (in Polish)

Isarin, R.F.B., 1997. Permafrost distribution and temperatures in Europe during the Younger Dryas. Permafrost and Periglacial Processes 8, 313-333.

https://doi.org/10.1002/(SICI)1099-1530(199709)8: 3<313::AID-PPP255>3.0.CO;2-E

Isarin, R.F.B. \& Renssen, H., 1999. Reconstructing and modelling late Weichselian climates: the Younger Dryas in Europe as a case study. Earth Science Review 48, 1-38. https://doi.org/10.1016/s0012-8252(99)00047-1

Isarin, RFB, Renssen, H. \& Vandenberghe, J., 1998. The impact of the North Atlantic Ocean on the Younger Dryas climate in northwestern and central Europe. Journal of Quaternary Sciences 13:5, 447-453. https://doi.org/10.1002/(SICI) 1099-1417(1998090) 13:5<447::AID-JQS402>3.0.CO;2-B

Jurkiewiczowa, I., 1961. Czwartorzęd dorzecza Widawki. Biuletyn Państwowego Instytutu Geologicznego 169, 175-211. (in Polish)

Kasse, C., Huijzer, A., Krzyszkowski, D., Bohncke, S. \& Coope, G., 1998. Weichselian Late Pleniglacial and Late-glacial depositional environments, Coleoptera and periglacial climatic records from central Poland (Bełchatów). Journal of Quaternary Science 13:5, 455-469.

https://doi.org/10.1002/(SICI)1099-1417(1998090) 13:5<455::AID-JQS398>3.0.CO;2-T

Klatkowa, H., 1989. Postwarciańskie kształtowanie górnych odcinków dolin. Przykłady z Wyżyny Łódzkiej. Acta Geographica Lodziensia 59, 61-74. (in Polish with French summary)

Klatkowa, H., 1996. Symptoms of the permafrost presence in Middle Poland during the last 150000 years. Biuletyn Peryglacjalny 35, 45-86.

Koster, E.A., 1995. Progress in cold-climate aeolian research. Quaestiones Geographicae, Special Issue 4, 155-163.

Koster, E.A. \& Dijkmans, J.W.A., 1988. Niveoaeolian deposits and denivation forms, with special reference to the Great Kobuk sand dunes, northwestern Alaska. Earth Surface Processes and Landforms 13, 153-170. https://doi.org/10.1002/esp.3290130206

Kozarski, S., 1993. Late Vistulian deglaciation and the expansion of the periglacial zone in NW Poland. Geologie en Mijnbouw 72, 143-157.

Kozarski, S., 1996. The periglacial impact on the deglaciation area of northern Poland after $20 \mathrm{kyr}$ BP. Biuletyn Peryglacjalny 34, 73-102.

Lowe, J.J., Ammann, B., Birks, H.H., Björck, S., Coope, G.R., Cwynar, L., De Beaulieu, J.-L., Mott, R.J., Peteet, D.M.
\& Walker, M.J.C., 1994. Climatic changes in areas adjacent to the North Atlantic during the last glacialinterglacial transition (14-9 ka BP): a contribution to IGCP-253. Journal of Quaternary Sciences 9, 185-198. https://doi.org/10.1002/jqs.3390090215

Manikowska, B., 1985. O glebach kopalnych, stratygrafii i litologii wydm Polski środkowej. Acta Geograhica Lodziensia 52, 137 p. (in Polish with English summary)

Manikowska, B., 1995. The apogee of Vistulian cold in the periglacial area of Central Poland - geological records. Quaternary Studies in Poland 13, 55-63.

Manikowska, B., 1996. Aeolian activity differentiation in the area of Poland during the period 20-8 ka BP. Biuletyn Peryglacjalny 34, 125-165.

Manikowska, B., 1997. Vistuliański eoliczny stożek osypiskowy na stoku doliny Pilicy w Inowłodzu. Acta Universitatis Lodziensis, Folia Geographica Physica 1, 209-220. (in Polish)

Marks, L., 1996. Rola martwego lodu w kształtowaniu mis jeziornych obecnych pojezierzy. Acta Geographica Lodziensia 71, 181-192. (in Polish with English summary)

Miall, A.D., 1978. Fluvial Sedimentology, vol. V. Canadian Society of Petroleum Geologists Memoir. Calgary, Alberta.

Mycielska-Dowgiałło, E., 1998. Znaczenie interpretacyjne brył piaszczystych i żwirowych w osadach fluwialnych i fluwioglacjalnych. In: Mycielska-Dowgiałło, E. (ed.) Struktury sedymentacyjne i postsedymentacyjne w osadach czwartorzędowych. Wydział Geografii i Studiów Regionalnych Uniwersytetu Warszawskiego, 15-120. (in Polish)

Olchowik-Kolasińska, J., 1962. Genetyczne typy struktur czynnej strefy zmarzliny. Acta Geographica (Universitatis) Lodziensia 10, 105 p. (in Polish with French summary)

Petera, J., 2002. Vistuliańskie osady dolinne w basenie uniejowskim i ich wymowa paleogeograficzna. Acta Geographica Lodziensia 83, 174 p. (in Polish with English summary)

Petera-Zganiacz, J., 2016. Czynniki determinujące zróżnicowanie inwolucji późnovistuliańskich w północno-zachodniej części regionu łódzkiego. Acta Universitatis Lodziensis, Folia Geographica Physica 15, 45-54. (in Polish)

Petera-Zganiacz, J. \& Dzieduszyńska, D.A., 2017. Palaeoenvironmental proxies for permafrost presence during the Younger Dryas, central Poland. Permafrost and Periglacial Processes 28:4, 726-740. https://doi.org/10.1002/ppp.1956

Petera-Zganiacz, J., Dzieduszyńska, D.A., Twardy, J., Pawłowski, D., Płóciennik, M., Lutyńska, M. \& Kittel, P., 2015. Younger Dryas flood events: A case study from the middle Warta River valley (Central Poland). Quaternary International 386, 55-69. https://doi.org/10.1016/j.quaint.2014.09.074 
Rasmussen, S.O., Bigler, M., Blockley, S.P., Blunier, T., Buchardt, S.L., Clausen, H.B., Cvijanovic, I., DahlJensen, D., Johnsen, S.J., Fischer, H., Gkinis, V., Guillevic, M., Hoek, W.Z., Lowe, J.J., Pedro, J.B., Popp, T., Seierstad, I.K., Steffensen, J.P., Svensson, A.M., Vallelonga, P., Vinther, B.M., Walker, M.J.C., Wheatley, J.J. \& Winstrup, M., 2014. A stratigraphic framework for abrupt climatic changes during the Last Glacial period based on three synchronized Greenland ice-core records: refining and extending the INTIMATE event stratigraphy. Quaternary Science Reviews 106, 14-28. https://doi.org/10.1016/j.quascirev.2014.09.007

Reimer, P.J., Bard, E., Bayliss, A., Beck, W.J., Blackwell, P.G., Bronk Ramsey, Ch., Buck, C.E., Cheng, H., Edwards, R.L., Friedrich, M., Grootes, P.M., Guilderson, T.P., Haflidason, H., Hajdas, I., Hatt_e, Ch., Heaton, T.J., Hoffmann, D.L., Hogg, A.G., Hughen, K.A., Kaiser, K.F., Kromer, B., Manning, S.W., Niu, M., Reimer, R.W., Richards, D.A., Scott, E.M., Southon, J.R., Staff, R.A., Turney, Ch.S.M. \& van der Plicht, J., 2013. IntCal13 and Marine13 radiocarbon age calibration curves 0-50,000 Years cal BP. Radiocarbon 55, 1869-1887. https://doi.org/10.2458/azu_js_rc.55.16947

Renssen, H., Isarin, R.F.B., Vandenberghe, J., Lautenschlager, M. \& Schlese, U., 2000. Permafrost as critical factor in paleoclimate modelling: the Younger Dryas case in Europe. Earth and Planetary Science Letters 176, 1-5. https://doi.org/10.1016/S0012-821X(99)00322-2

Roman, M., Dzieduszyńska, D. \& Petera-Zganiacz, J., 2014. Łódź Region and its northern vicinity under Vistulian Glaciation conditions. Quaestiones Geographicae 54, 55-68.

Scalenghe, R., Certini, G., Corti, G., Zanini, E. \& Ugolini, F.C., 2004. Segregated ice and liquifaction effects on compaction of fragipans. Soil Science Society of American Journal 68, 204-214. https://doi.org/10.2136/sssaj2004.2040
Starkel, L., Michczyńska, D.J., Gębica, P., Kiss, T., Panin, A. \& Perşoiu, I., 2015. Climatic fluctuations reflected in the evolution of fluvial systems in Central-Eastern Europe (60-8 ka BP). Quaternary International 388, 97-111. https://doi.org/10.1016/j.quaint.2015.04.017

Turkowska, K., 1988. Rozwój dolin rzecznych na Wyżynie Łódzkiej w późnym czwartorzędzie. Acta Geographica Lodziensia 57, 157 p. (in Polish with French summary)

Turkowska, K., 2006. Geomorfologia regionu łódzkiego. Wyd. UŁ, Łódź, 238 p. (in Polish)

Turkowska, K. \& Dzieduszyńska, D., 2011. Local evidence of landform evolution vs. global changes - a case of Younger Dryas study in the upper Ner Valley system, central Poland. Geographia Polonica 84, 147-162.

Turkowska, K., Petera, J., Forysiak, J. \& Miotk-Szpiganowicz, G., 2000. Morfogeneza powierzchni Kotliny Kolskiej w okolicach Koźmina. Acta Geographica Lodziensia 78, 98-134. (in Polish with English summary)

Turkowska, K., Forysiak, J., Petera, J. \& Miotk-Szpiganowicz, G., 2004. A Warta River system during the Younger Dryas in the Koło Basin (Middle Poland). Quaestiones Geographicae 23, 83-107.

Twardy, J., 2008. Transformacja rzeźby centralnej części Polski Środkowej w warunkach antropopresji. Wyd. UŁ, Łódź, 292 p. (in Polish)

Van der Hammen, T. \& Maarleveld, G.C., 1952. Genesis and dating of the periglacial phenomena at the eastern fringe of the Veluwe. Geology en Mijnbouw 14, 47-54.

Van Vliet-Lanoë, B. \& Langhor, R., 1981. Correlation between fragipans and permafrost with special reference to Weichsel silty deposits in Belgium and northern France. Catena 8, 137-154. https://doi.org/10.1016/S0341-8162(81)80009-4

Zieliński, T., 2015. Sedymentologia. Osady rzek i jezior. Wyd. Nauk. UAM, Poznań, 594 p. (in Polish) 